\title{
Sumber Tenaga, Komunikasi, Usia, Lama Kerja Dan Pelatihan Perawat Dapat Meningkatkan Pelaksanaan Perawatan Bayi Prematur Di Ruang Perinatologi
}

\author{
Erna Julianti $^{1^{*}}$, Fajar Tri Waluyanti ${ }^{2}$, Allenidekania ${ }^{3}$ \\ ${ }^{1}$ Akademi Keperawatan Pangkalpinang \\ 2,3 Departemen Keperawatan Anak Fakultas Ilmu Keperawatan, Universitas Indonesia \\ *Email: adex_erna90@yahoo.com
}

\section{Kata kunci : \\ Pelaksanaan \\ perawatan, bayi \\ prematur \\ Keywords : \\ Implementation of \\ care, premature \\ babies}

Info Artikel:

Tanggal dikirim:

22 Juni 2020

Tanggal direvisi:

16 September 2020

Tanggal diterima :

20 Oktober 2020

DOI Artikel:

10.33862/citradelima.

v4i2.104

Halaman: 106-111

\begin{abstract}
Abstrak
Kompleksitas perawatan bayi yang intensif menyebabkan ada perawatan rutin yang terlewatkan sehingga dapat memperpanjang lama perawatan, risiko rawat ulang, meningkatkan komplikasi bayi, dan menurunkan kepuasan orang tua. Penelitian cross sectional ini bertujuan untuk mengidentifikasi sumber tenaga, komunikasi, usia, lama kerja dan pelatihan berhubungan dengan pelaksanaan perawatan bayi prematur di ruang Perinatologi. Teknik consecutive sampling dilakukan untuk memilih 59 perawat yang merawat bayi prematur di ruang Perinatologi Rumah Sakit Jakarta. Analisis dilakukan secara univariat,dan bivariate. Uji statistik yang digunakan adalah uji pearson dan regresi linear. Hasil analisis didapatkan bahwa ada hubungan yang signifikan antara sumber tenaga perawat, komunikasi, usia, lama kerja perawat, dan pelatihan dengan pelaksanaan perawatan bayi prematur dengan p Value 0,014, 0,004, <0,001, <0,001, $<0,001$. Bagi pelayanan keperawatan dapat menjadi evaluasi terhadap kinerja perawat untuk meningkatkan kualitas perawatan bayi prematur.
\end{abstract}

\section{Human Resources, Communication, Age, Length of Work and Nurse Training Can Improve Implementation of Premature Baby Care in the Perinatology Room}

\begin{abstract}
Complexity of intensive care of premature babies causes some routine nursing cares are overlooked which may lead to extension of length of stay, risk of rehospitalization, additional disease' complications, and decrease of parents' satisfaction. This crosssectional study aimed to identify manpower sources, communication, age, long work and nurse training related to the implementation of preterm infant care. the consecutive sampling technique was used to select 59 nurses caring for premature babies in the Perinatology Room at the Jakarta Hospital. The analysis was carried out univariately, and bivariately. The statistical test used is the Pearson test and linear regression. The results of the analysis found that there is a significant relationship between the source of nurses, communication, age, length of service of nurses, and training with the implementation of preterm baby care with $\mathrm{p}$ Value $0.014,0.004,<0.001,<0.001$, $<0.001$. Nursing care should be evaluated to improve the performance of nurses and the quality of care of premature babies.
\end{abstract}




\section{PENDAHULUAN}

Bayi prematur mempunyai kecenderungan lebih tinggi untuk terjadinya kesakitan sebesar 25-50\% dibandingkan dengan bayi cukup bulan sebesar 8-10\% (Blackburn, 1998 dalam Rustina, 2014). Bayi prematur juga merupakan kelompok bayi risiko tinggi terjadinya cerebral palsy sebesar 5-21\%, retardasi mental 10-20\%, gangguan penglihatan $2-11 \%$, gangguan pendengaran 1$3 \%$, gangguan motorik $24 \%$, dan masalah perilaku $25 \%$ (Aarnoudse-Moens, Smidts, Oosterlaan, Duivenvoorden, \& Weisglas-Kuperus, 2009; Brodsky \& Ouellette, 2008). Prematuritas merupakan faktor utama tingginya angka mortalitas, morbiditas dan disabilitas neonatus sehingga bayi prematur membutuhkan perhatian dan perawatan khusus di ruang perawatan neonatus.

Perawat mempunyai peranan penting dalam meningkatkan kesehatan fisik bayi prematur, memenuhi kebutuhan bayi prematur yang kompleks, memperhatikan tumbuh kembangnya, serta sensitif terhadap kondisi psikologis orang tua dengan cara memberikan perawatan yang komprehensif dan lengkap. Namun, Hasil penelitian yang dilakukan oleh Rochefort dan Clarke (2010) menyatakan bahwa sebanyak 339 perawat melakukan missed nursing care di NICU Kanada. Tubbs-Cooley, Pickler, Younger, dan Mark (2014) juga menyatakan sebanyak 120 perawat melakukan missed nursing care di NICU Amerika Serikat. Jenis perawatan yang terlewatkan yaitu perencanaan pulang, memberikan pendidikan kesehatan kepada orang tua, serta dukungan perawatan, operan, perawatan mulut pada bayi yang menggunakan ventilator dan keterlibatan orang tua dalam perawatan.

Banyak faktor yang mempengaruhi asuhan keperawatan yang terlewatkan yaitu karakterisik unit, staffing, beban kerja, sumber materi, komunikasi, kerja sama tim, dan karakteristik demografi perawat (Blackman et al., 2015; Castner, Wu, \& Dean-Baar, 2014). Hal ini sejalan dengan penelitian yang dilakukan oleh Al-Kandari, dan Thomas (2009) menyatakan bahwa usia, jenis kelamin, tingkat pendidikan perawat dan pengalaman perawat sangat mempengaruhi asuhan keperawatan yang terlewatkan. Dampak asuhan keperawatan yang terlewatkan bagi pasien yaitu meningkatnya lama rawat, rawat ulang, nyeri dan ketidaknyamanan, lamanya pencapaian menyusui oral penuh dan menurunkan kepuasan pasien (Kalisch et al., 2009; Tubbs-Cooley, Pickler, \& Meinzen-Derr, 2015).

Tim keperawatan perlu melakukan penilaian yang tepat terhadap sumber tenaga perawat, keterampilan komunikasi dan kerja sama tim untuk meningkatkan kualitas pelayanan keperawatan. Suatu pelayanan keperawatan yang baik jika perawatan yang diberikan dapat memenuhi kebutuhan bayi prematur serta memberikan dukungan emosional dan informasional kepada orang tua dalam merawat bayinya. Hal tersebut yang mendasari peneliti untuk mengidentifikasi sumber tenaga, komunikasi, usia, lama kerja, pelatihan perawat berhubungan dengan pelaksanaan perawatan bayi prematur di ruang Perinatologi.

\section{METODE}

Penelitian ini merupakan penelitian korelasi dengan pendekatan cross sectional. Sampel penelitian ini adalah perawat yang merawat bayi prematur di ruang Neonatus Rumah Sakit Di Jakarta sebanyak 59 perawat. Consecutive sampling digunakan untuk menentukan sampel tersebut. Instrumen pada penelitian ini adalah Missed care survey. Missed care survey terdiri dari bagian B1 untuk menilai pelaksanaan perawatan bayi prematur yang terdiri 34 pernyataan dengan validitas $0.401-0.752$ dengan reabilitas 0.959 . Kuesioner bagian B2 tentang alasan melewatkan perawatan bayi terdiri dari tiga subskala yaitu sumber tenaga kerja untuk pernyataan nomor $1-11$, sumber material pernyataan nomor 12-17, dan komunikasi dan kerjasama pernyataan nomor 18-24. Uji reliabilitas instrument bagian $\mathrm{B} 2$ menggunakan test retest dengan pearson korelasi koefisiensnya sebesar $0,86(\mathrm{P}<0,001$, interval kepercayaan 0,79-0.96) sehingga dapat disimpulkan instrument ini reliable.

Analisis pada penelitian ini adalah univariat dan bivariate. Analisis univariat menggunakan mean, standar deviasi dan CI 95\%. Analisis bivariat menggunakan analisis korelasi Pearson untuk mengetahui hubungan antara sumber tenaga, komunikasi, usia, lama kerja perawat, dan pelatihan perawat dengan pelaksanaan perawatan bayi prematur. Penelitian ini mendapatkan izin etik dari Fakultas Ilmu Keperawatan Universitas Indonesia.

\section{HASIL DAN PEMBAHASAN}

Hasil

Tabel 1. Distribusi Frekuensi Karakteristik Responden berdasarkan Pelatihan Perawat di Ruang Perinatologi $(\mathrm{n}=59)$

\begin{tabular}{lcc}
\hline Karakteristik responden & (n) & $(\boldsymbol{\%})$ \\
\hline Pelatihan Perawat & & \\
Belum pernah mengikuti pelatihan & 26 & $44,1 \%$ \\
Pernah mengikuti pelatihan & 33 & $55,9 \%$ \\
\hline
\end{tabular}

http://jurnalilmiah.stikescitradelima.ac.id/index.php/JI Vol.4 No.2 Januari 2021 
Tabel 1 menunjukkan bahwa dari 59 responden didapatkan sebagian besar perawat di ruang Perinatologi dua Rumah Sakit di Jakarta pernah mengikuti pelatihan perawatan bayi sebesar 55,9\%.

Tabel 2. Distribusi Perawat berdasarkan Usia, Lama Bekerja, pelaksanan perawatan bayi prematur, sumber tenaga, dan komunikasi perawat di Ruang Perinatologi $(\mathrm{n}=59)$

\begin{tabular}{lccc}
\hline $\begin{array}{l}\text { Karakteristik } \\
\text { responden }\end{array}$ & Mean & $\begin{array}{c}\text { Standar } \\
\text { Deviasi }\end{array}$ & Median \\
\hline Usia Perawat & 35,17 & 10,14 & 32 \\
Lama Kerja Perawat & 41,34 & 3,78 & 36 \\
Pelaksanaan & & & \\
Perawatan & 161,93 & 5,37 & 162 \\
Sumber Tenaga & 17,29 & 7,93 & 14 \\
Komunikasi & 9,44 & 4,01 & 8 \\
\hline
\end{tabular}

Variabel usia perawat, sumber tenaga, dan komunikasi perawat mempunyai sebaran data tidak normal sehingga menggunakan median. Berdasarkan tabel 2 menunjukkan bahwa dari 59 responden, perawat ruang Rawat Neonatus mempunyai nilai tengah usia 32 tahun, Sumber tenaga perawat mempunyai nilai tengah 14, dan komunikasi mempunyai nilai tengah 8 . Selain itu, variabel lama kerja perawat dan pelaksanaan mempunyai sebaran data normal sehingga mengunakan mean. Rata-rata lama kerja perawat di Ruang Rawat Neonatus yaitu 41,34 bulan $(\mathrm{SD}=3,78)$ dan nilai ratarata pelaksanaan perawatan bayi prematur sebesar $161,93(\mathrm{SD}=5,37)$.

Tabel 3. Hubungan antara Sumber Tenaga Perawat, Komunikasi, Usia, dan lama Kerja Perawat dengan Pelaksanaan Perawatan Bayi Prematur di Ruang Perinatologi

\begin{tabular}{lcc}
\hline \multicolumn{1}{c}{ Variabel } & \multicolumn{2}{c}{$\begin{array}{c}\text { Pelaksanaan Perawatan Bayi } \\
\text { Prematur }\end{array}$} \\
\cline { 2 - 3 } & $\mathbf{R}$ & $\boldsymbol{p}$ Value \\
Sumber Tenaga & $-0,319$ & 0,014 \\
Komunikasi & $-0,269$ & 0,004 \\
Usia Perawat & 0,493 & $<0,001$ \\
Lama Kerja Perawat & 0,509 & $<0,001$ \\
\hline
\end{tabular}

Tabel 3 menunjukkan bahwa terdapat hubungan yang signifikan antara sumber tenaga perawat, komunikasi, usia dan lama kerja perawat dengan pelaksanaan perawatan bayi prematur dengan $p$ Value $<0,05$. Sumber tenaga, komunikasi, usia dan lama kerja perawat mempunyai kekuatan korelasi sedang dan sumber material mempunyai kekuatan korelasi lemah. Usia dan lama kerja perawat mempunyai arah korelasi positif artinya semakin tinggi usia dan lama kerja maka semakin tinggi pelaksanaan perawatan bayi prematur di ruang Rawat Neonatus $\left(r_{4}=0,493, r_{5}=0,509\right)$. Sumber tenaga, sumber material, dan komunikasi mempunyai arah korelasi negatif artinya semakin tinggi sumber tenaga, sumber material, dan komunikasi maka semakin rendah melewatkan pelaksanaan perawatan bayi prematur $\left(r_{1}=-0,319, r_{2}=-0,247, r_{3}=-0,269\right)$.

Tabel 4. Hubungan antara Pelatihan dan Pendidikan Perawat dengan Pelaksanaan Perawatan Bayi Prematur di Ruang Perinatologi

\begin{tabular}{lccc}
\hline Variabel & \multicolumn{3}{c}{$\begin{array}{c}\text { Pelasanaan Perawatan } \\
\text { Bayi Prematur }\end{array}$} \\
\cline { 2 - 4 } & Mean & SD & P value \\
\hline $\begin{array}{l}\text { Pelatihan } \\
\text { - Belum pernah } \\
\text { mengikuti pelatihan }\end{array}$ & 157,08 & 3,67 & \\
- Pernah mengikuti & 165,76 & 2,74 & \\
$\quad$ pelatihan & & & \\
\hline
\end{tabular}

Tabel 4 menunjukkan bahwa perawat yang pernah mengikuti pelatihan mempunyai nilai rata-rata tertinggi pelaksanaan perawatan bayi prematur sebesar 165,76 (SD 2,74). Hasil analisis didapatkan bahwa terdapat perbedaan yang signifikan antara pelaksanaan perawatan bayi prematur diantara perawat yang belum pernah mengikuti pelatihan dan perawat yang pernah mengikuti pelatihan ( $p$ Value $=<0,001$ ). Selanjutnya, perawat dengan pendidikan profesi mempunyai rata-rata pelaksanaan perawatan bayi prematur yang paling tinggi sebesar 162,18. Hasil analisis didapatkan bahwa tidak ada perbedaan yang signifikan pelaksanaan perawatan bayi prematur antara pendidikan vokasi dan pendidikan profesi (p Value $=0,786)$

\section{Pembahasan}

a. Hubungan antara Pelatihan Lama Bekerja dan Usia Perawat dengan Pelaksanaan Perawatan Bayi Prematur

Hasil penelitian ini juga didapatkan bahwa terdapat perbedaan yang signifikan pelaksanaan perawatan bayi prematur antara belum pernah mengikuti pelatihan dengan pernah mengikuti pelatihan. Rata-rata pelaksanaan perawatan bayi prematur yang mengikuti pelatihan lebih tinggi daripada tidak mengikuti pelatihan. Mohammed, Bayoumi, dan Mahmoud (2014) juga menyatakan bahwa perawat yang mengikuti pelatihan khususnya pelatihan perawatan bayi dapat meningkatkan pengetahuan dan keterampilan perawat untuk melaksanakan perawatan bayi prematur sehingga kualitas pelayanan yang diberikan berkualitas. Hasil penelitian ini didapatkan bahwa terdapat hubungan yang signifikan antara usia perawat, dan lama

http://jurnalilmiah.stikescitradelima.ac.id/index.php/JI

Vol.4 No.2 Januari 2021 
bekerja dengan pelaksanaan perawatan bayi prematur dengan korelasi sedang dan arah korelasi positif artinya semakin tua usia perawat dan lama bekerja semakin tinggi melaksanakan perawatan bayi prematur.

Hal ini sejalan dengan penelitian yang dilakukan oleh Tschannen, Kalisch dan Lee (2010) yang menyatakan bahwa ada hubungan yang signifikan antara usia perawat dengan pelaksanaan perawatan pasien. Semakin tua perawat, dan semakin lama bekerja maka semakin tinggi pelaksanaan perawatan pasien. Hasil penelitian $\mathrm{Al}$ Kandari dan Thomas (2009) juga menyatakan bahwa ada hubungan antara usia perawat dengan pelaksanaan perawatan pasien. Hal ini karena perawat berusia tua memiliki manajemen waktu, keterampilan, pengalaman kerja dan tanggung jawab dalam melaksanakan perawatan kepada pasien setiap shift. Robbins dan Judge (2008) menyatakan semakin bertambah usia maka pekerja akan membawa sifat-sifat positif dalam melaksanakan pekerjaannya seperti pengalaman, perilaku etik, dan komitmen dalam menjaga kualitas pekerjaannya.

Selain itu, McHugh dan Lake (2010) menyatakan bahwa lama bekerja berhubungan dengan keahlian dan keterampilan dalam melaksanakan perawatan. Robbins dan Judge (2008) juga menyatakan lama bekerja menjadi dasar pemikiran yang baik terhadap produktivitas karyawan. Perawat yang bekerja kurang dari 4 tahun mempunyai kesalahan perawatan tinggi, ketidakpuasan bekerja dan kualitas perawatan yang buruk (Kanai-Park et al., 2008).

b. Hubungan antara Sumber Tenaga, dan Komunikasi dengan Pelaksanaan Perawatan Bayi Prematur

Alasan perawat melewatkan perawatan bayi prematur terdiri dari tiga yaitu sumber tenaga, sumber material, dan komunikasi. Hasil penelitian ini didapatkan bahwa ada hubungan yang signifikan antara sumber tenaga perawat dengan pelaksanaan perawatan bayi. Semakin tinggi sumber tenaga maka semakin rendah perawat melewatkan perawatan bayi. Penelitian ini sejalan dengan penelitian yang dilakukan oleh Blackman et al. (2015) menyatakan bahwa ada hubungan yang signifikan antara sumber tenaga dengan asuhan keperawatan yang terlewatkan. Semakin tinggi sumber tenaga perawat maka semakin rendah perawat melewatkan perawatan.
Berdasarkan perhitungan Depkes (2005) didapatkan total kebutuhan perawat di Rumah Sakit A sebanyak 40 perawat dan di Rumah Sakit B sebanyak 32 perawat. Akan tetapi, jumlah perawat pelaksana di RS A sekarang sebanyak 36 perawat dan RS B sebanyak 31 perawat. Hal ini menujukkan bahwa jumlah perawat di RS A hampir mendekati dengan total kebutuhan perawat sedangkan jumlah perawat di RS B kurang dari total kebutuhan perawat. Ratio perawat dengan pasien 1: 6-8. Sumber tenaga perawat bukan hanya dilihat dari jumlah tenaga perawat tetapi adanya faktor lain yang menyebabkan perawat melewatkan perawatan bayi.

Sumber tenaga yang menyebakan perawat melewatkan perawatan dalam penelitian ini yaitu kondisi kritis pasien, jumlah pasien yang meningkat, dan aktivitas masuk dan keluar pasien yang tinggi. Hasil penelitian ini sejalan dengan penelitian yang dilakukan Moreno-Monsivái et al. (2015) yang menyatakan bahwa sumber tenaga yang juga menyebabkan perawat melewatkan perawatan berupa kondisi kritis pasien, jumlah pasien tidak terduga, pihak lain tidak tersedia, tidak seimbangnya penugasan, kurang tersedianya waktu untuk menyelesaikan perawatan, dan minimnya jumlah tenaga bantuan. Suatu rumah sakit memiliki cukup perawat dengan keterampilan khusus sangat penting untuk memenuhi kebutuhan pasien, akan tetapi jika perawat dikurangi bahkan perawat melewatkan tugas perawatan maka akan meningkatkan risiko yang merugikan pasien dan perawat (Kalish \& Lee, 2010).

Dampak bagi bayi yaitu meningkatnya lama rawat, tingginya infeksi, kegagalan discharge, meningkatnya nyeri dan ketidaknyamanan, cacat fisik, bahkan kematian. Selain itu, perawat yang melewatkan perawatan akan berdampak pada kualitas pelayanan dan biaya perawatan (Kalisch, Landstrom, \& Williams, 2009). Upaya yang dilakukan supaya tenaga perawat tidak melewatkan perawatan yaitu pelatihan. Liaw, Yang, Chang, Chou, dan Chao (2009) menyatakan hal terpenting dalam perawatan bayi prematur adalah peningkatan kemampuan dan kreativitas perawat melalui program pelatihan perawatan bayi. Schuckhart (2010) juga menyatakan tenaga perawat harus mempunyai pengetahuan, pedoman etika dan keterampilan keperawatan untuk meningkatkan kualitas pelayanan keperawatan. Selain itu, perawat diajarkan standar perawatan dalam melaksanakan perawatan melalui kebijakan, prosedur dan kriteria

http://jurnalilmiah.stikescitradelima.ac.id/index.php/JI Vol.4 No.2 Januari 2021 
evaluasi di tempat kerja (Kalisch, Landstrom, \& Williams, 2009).

Dampak bagi perawat jika melewatkan perawatan yaitu stres, ketidakpuasan terhadap pekerjaannya, pindah dan keluar dari tempat kerja (Watson, 2002). Upaya yang dilakukan pada perawat yaitu pengurangan beban kerja (Alotaibi, Paliadelis, \& Valenzuela, 2016). Hal ini karena tingginya beban kerja akan mempengaruhi perawat dalam memberikan perawatan kepada pasien.

Alasan missed care yang lain adalah komunikasi. Komunikasi yang menyebakan perawat melewatkan perawatan yaitu delegasi antar perawat tidak efektif, kurangnya dukungan atau kerja sama, dan anggota tim keperawatan tidak memberikan informasi bahwa perawatan tidak diberikan. Hasil Penelitian ini didapatkan bahwa ada hubungan yang signifikan antara komunikasi dengan pelaksanaan perawatan bayi prematur. Semakin tinggi komunikasi, maka semakin rendah melewatkan perawatan bayi prematur. Hasil penelitian ini sejalan dengan penelitian yang dilakukan oleh Castner dan Dean-Bar (2015) yang menyatakan ada hubungan antara komunikasi dengan asuhan keperawatan yang terlewatkan

Moreno-Monsivai et al. (2015) menyatakan bahwa faktor komunikasi yang menjadi alasan melewatkan perawatan berupa alokasi yang tidak seimbang dari pasien, terlalu banyak tugas yang harus dilakukan untuk pasien yang dirawat dan dipersiapkan pulang, kurang dukungan dari anggota tim dan kegagalan komunikasi dengan tenaga medis.

Kripalani et al. (2007) menyatakan bahwa kurangnya komunikasi dan pengiriman informasi dapat mempengaruhui perawatan pasien dan menurunkan kualitas perawatan. Selain itu, dampak bagi pasien berhubungan dengan keselamatan pasien (Rosenstein \& O'Daniel, 2008). Komunikasi efektif, akurat, lengkap, jelas, tepat waktu dan mudah dipahami oleh pasien akan mengurangi kesalahan, dan menghasilkan peningkatan keselamatan pasien.

\section{SIMPULAN}

Penelitian ini menunjukkan bahwa terdapat hubungan yang signifikan antara usia, lama kerja perawat, pelatihan, sumber tenaga perawat, dan komunikasi, dengan pelaksanaan perawatan bayi prematur.

\section{DAFTAR PUSTAKA}

Aarnoudse-Moens, C., Smidts, D., Oosterlaan, J., Duivenvoorden, H., \& Weisglas-Kuperus, N. (2009). Executive function in very preterm children at early school age. Journal of Abnormal Child Psychology, 37(7), 981-993 13p. doi:10.1007/s10802-009-9327-z

Al-Kandari, F., \& Thomas, D. (2009). Factors contributing to nursing task incompletion as perceived by nurses working in Kuwait general hospitals. Journal of Clinical Nursing, 18(24), $3430-$ doi:10.1111/j.13652702.2009.02795.x

Alotaibi, J., Paliadelis, P. S., \& Valenzuela, F. (2016). Factors that affect the job satisfaction of Saudi Arabian nurses. Journal of Nursing Management, 24(3), 275-282. doi:10.1111/jonm.12327

Blackman, I., Henderson, J., Willis, E., Hamilton, P., Toffoli, L., Verrall, C., \& ... Harvey, C. (2015). Factors influencing why nursing care is missed. Journal of Clinical Nursing, 24(1/2), 47-56 10p. doi:10.1111/jocn.12688.

Castner, J., Wu, Y. B., \& Dean-Baar, S. (2015). Multilevel model of missed nursing care in the context of hospital merger. Western Journal Of Nursing Research, 37(4), 441-461 21p. doi:10.1177/0193945914535670.

Kalisch B. J., Landstrom G. L., \& Hinshaw, A. S (2009). Missed nursing care: A concept analysis. Journal of Advanced Nursing, 65, 1509-17. doi: 10.1111/j.1365-2648.2009.05027.

Kalisch, B., \& Williams, R. (2009). Development and psychometric testing of a tool to measure missed nursing care. Journal of Nursing Administration, 39(5), 211-219 9p. doi:10.1097/NNA.0b013e3181a23cf5

Kripalani, S., LeFevre, F., Phillips, C. O., Williams, M. V., Basaviah, P., \& Baker, D. W. (2007). Deficits in communication and information transfer between hospital-based and primary care physicians: implications for patient safety and continuity of care. Jama, 297(8), 831-841.

Liaw, J., Yang, L., Chang, L., Chou, H., \& Chao, S. (2009). Improving neonatal caregiving through a developmentally supportive care training program. Applied Nursing Research, 22(2), 8693 8p. doi:10.1016/j.apnr.2007.05.001

Moreno-Monsivái, M. G., Moreno-Rodríguez, C., \& Interial-Guzmán, M. G. (2015). Missed Nursing 
Care in Hospitalized Patients. Aquichan, 15(3), 318328. doi: 10.5294/aqui.2015.15.3.2.

Miles, M. S., Holditch-Davis, D., Schwartz, T. A., \& Scher, M. (2007). Depressive symptoms in mothers of prematurely born infants. Journal of Developmental And Behavioral Pediatrics: JDBP, 28(1), 36-44.

Mohammed, S. A. R., Bayoumi, M. H., \& Mahmoud, F. S. (2014). The effect of developmentally supportive care training program on nurses' performance and behavioral responses of newborn infants. Journal of Education and Practice, 5 (6), 134-144

Papastavrou, E., Andreou, R., \& Efstathiou, G. (2013). Rationing of nursing care and nurse-patient outcomes: A systematic review of quantitative studies. The International Journal of Health Planningand Management, 29(1), 3-25. doi:10. 1002/hpm.2160.

Rochefort C.M. \& Clarke S.P. (2010). Nurses work environments, care rationing, job outcomes and quality of care on neonatal units. Journal of Advanced Nursing, 66(10), 2213-2224. doi:10.1111/j.1365-2648.2010.05376.x.

Robbins, S.P., \& Judge, T.A. (2008). Perilaku organisasi. Jakarta: Salemba

Rosenstein, A. H., \& O'Daniel, M. (2008). A survey of the impact of disruptive behaviors and communication defects on patient safety. The Joint Commission Journal on Quality and Patient Safety, 34(8), 464-471

Russell, G., Sawyer, A., Rabe, H., Abbott, J., Gyte, G., Duley, L., \& Ayers, S. (2014). Parents' views on care of their very premature babies in neonatal intensive care units: A qualitative study. $B M C$ Pediatrics, $\quad 14, \quad 230$ doi:http://dx.doi.org/10.1186/1471-2431-14-230.

Rustina, Y. (2015). Bayi prematur: Perspektif keperawatan. Jakarta: Sagung Seto.

Sawyer, A., Rabe, H., Abbott, J., Gyte, G., Duley, L., \& Ayers, S. (2013). Parents' experiences and satisfaction with care during the birth of their very preterm baby: a qualitative study. BJOG: An International Journal of Obstetrics \& Gynaecology, 120(5), 637-643. DOI: 10.1111/1471-0528.12104.

Schuckhart, M. (2010). MISSCARE nursing survey: A secondary data analysis (Order No. 1483603). Available from ProQuest Dissertations \& Theses Global. (822181643). Retrieved from http://search.proquest.com/docview/822181643? accountid=17242.

Tschannen, D., Kalisch, B. J., \& Lee, K. H. (2010). Missed nursing care: The impact on intention to leave and turnover. Canadian Journal of Nursing Research, 42(4), 22-39 18p.

Tubbs-Cooley H.L., Pickler R.H., Younger J.B. \& Mark B.A. (2014). A descriptive study of nursereported missed care in neonatal intensive care units. Journal of Advanced Nursing. doi: 10.1111/jan.12578.

Tubbs-Cooley, H. L., Pickler, R. H., \& Meinzen-Derr, J. K. (2015). Missed oral feeding opportunities and preterm infants' time to achieve full oral feedings and neonatal intensive care unit discharge. American Journal of Perinatology, 32 (1). doi:http://dx.doi.org/10.1055/s-00341372426

WHO. (2014). Preterm birth. Geneva: WHO.

http://jurnalilmiah.stikescitradelima.ac.id/index.php/JI Vol.4 No.2 Januari 2021 